\title{
Miranda
}

Revue pluridisciplinaire du monde anglophone /

Multidisciplinary peer-reviewed journal on the English-

speaking world

$6 \mid 2012$

Marking the Land in North America

\section{"I have made a footprint, through it the blades push upward." Marking the Land while Talking to the Moon}

\section{Lionel Larre}

\section{OpenEdition \\ Journals}

Electronic version

URL: http://journals.openedition.org/miranda/2819

DOI: $10.4000 /$ miranda.2819

ISSN: 2108-6559

\section{Publisher}

Université Toulouse - Jean Jaurès

\section{Electronic reference}

Lionel Larre, "'I have made a footprint, through it the blades push upward." Marking the Land while Talking to the Moon", Miranda [Online], 6 | 2012, Online since 28 June 2012, connection on 16 February 2021. URL: http://journals.openedition.org/miranda/2819 ; DOI: https://doi.org/10.4000/miranda.2819

This text was automatically generated on 16 February 2021.

Miranda is licensed under a Creative Commons Attribution-NonCommercial-NoDerivatives 4.0 International License. 


\title{
"I have made a footprint, through it the blades push upward." Marking the Land while Talking to the Moon
}

\author{
Lionel Larre
}

\section{Introduction}

1 After centuries of Euroamerican misrepresentations of the relationship the American Indians have had with the land they inhabit, some American Indian authors have written about how to relate to one's environment. American Indians are often essentialized as ecological beings living in such harmony with nature that they left no markings on the land they occupied. This view has been challenged recently by scholars who hold the Indians responsible for the extinction of the Pleistocene megafauna. These two extreme views encompass a debate that has been raging for over a decade since the publication of The Ecological Indian: Myth and History, by Shepard Krech III in 1999. Although this debate often manifests itself in unfortunately simplistic terms, it has also produced balanced assessments of the impact Native Americans did have on their environment. In this paper I propose to study one early nuanced vision located somewhere between these two extremes. This vision is mainly the one of an Osage writer, John Joseph Mathews (1895-1979), supported by other authors such as Louis Owens (Choctaw-Cherokee), N. Scott Momaday (Kiowa), and Luther Standing Bear (Lakota). It is imperative to keep in mind, though, that the views of Mathews are not to be essentialized as "Native American views" of the land and the human impact on it. Biologically, Mathews was "partly" a Native American writer (one eighth Osage), and culturally he was a cosmopolitan world-traveller who had grown up in Osage country. In Talking to the Moon, he writes above all as a native of the Blackjacks, an isolated area named after the oak trees that cover the hills, rather than a Native American. He defines himself as literally indigenous to the Blackjacks, that is to say engendered by this "little corner of the earth which had given [him] being" (2). 
2 In and of himself, Mathews embodies the complex relationship the Native Americansand virtually everybody else, for that matter-have with their environment. On the one hand, he was a member of the Osage tribe, often referred to as the "richest tribe or nation of people in the world" (White 202), notably after the oil bonanza of the 1920s, which increased his personal fortune to the point that, at age 29, he "found himself under no particular compulsion to seek gainful employment" (Wilson 271). On the other hand, he lived for about ten years alone observing nature around his small, rustic house in the blackjack-covered Osage hills, near Pawhuska, Osage County, Oklahoma. In 1945, Mathews published Talking to the Moon, a nature writing essay as defined by Tom Pughe and Michel Granger as a "hybrid writing between natural history, autobiography, philosophy and fiction" (4). In this book, Mathews tells of his life during the ten years he spent in the Blackjacks, living in a precarious balance with his environment, and writes down his observations of his natural surroundings as well as his philosophical reflections. Far from essentializing how all Native Americans relate to their environment, though, Mathews writes, first and foremost, about how he, as a native of this "corner of the earth," relates to his landscape and the beings that inhabit it. Doing so, however, he tries to understand how this particular place gave birth to and shaped the culture of his people.

3 In a foreword to the 1981 edition of the book, Elizabeth Mathews writes that "this is John Joseph Mathews' Walden. It is a book that a Thoreau or a Muir might write, but it is a Walden of the plains and prairies, of the 1930s and 1940s, by a Native American" (ix). According to A. LaVonne Brown Ruoff, Mathews deliberately places Talking to the Moon in the literary tradition characterized by Henry David Thoreau and John Muir's My First Summer in the Sierra. Mathews's statement of purpose is certainly reminiscent of Thoreau's. When the latter writes that he "went to the woods because [he] wished to live deliberately, to front only the essential facts of life, and see if [he] could not learn what it had to teach, and not, when [he] came to die, discover that [he] had not lived" (Thoreau 72), Mathews wrote this:

I wanted to express my harmony with the natural flow of life on my bit of earth by physical action. Word symbols couldn't satisfy me as an expression; there was much that was inexpressible; there were flying in the moonlight, the Grand Canyon, desert sunsets, riding over the Osage prairie in June. Word symbols seemed futile and pale [...] Physical action and living to the very brim each day in harmony with the life about me were exhausting and therefore completely satisfactory (16).

Both authors express an irrepressible urge to touch ground, to establish an immediate and direct contact with the earth, to have with it a relationship not mediated by the artificialities of modern life. Both Thoreau and Mathews went to the woods to pull themselves "out of the roaring river of civilization to rest for a while" (Mathews 3).

Coming back to the Blackjacks after a cosmopolitan life that took him to Europe and North Africa, Mathews anticipated Momaday's injunction that "once in his life a man ought to concentrate his mind upon the remembered earth [...]. He ought to give himself up to a particular landscape in his experience, to look at it from as many angles as he can, to wonder about it, to dwell upon it" ("An American Land Ethic" 45). Dwell upon it is exactly what Mathews did, by "physical action" (16).

6 His goal was "to learn something of the moods of the little corner of the earth which had given [him] being" (2). To that end, he had to actually mark the land, and reflect on these markings, as well as on the markings the land left on him and his people. Finally, he would produce his own markings about the land. According to Luther Standing Bear, 
because "Nature makes the man to fit his surroundings", "then a description of the land partly, at least, describes the people" (42). By producing markings about the land, then, Mathews would also write of his people and of himself, a form of writing one might call auto-topo-graphy, that is to say a minute description of the land as a way to write about one's life.

7 Markings on the land, markings from the land, and markings about the land: my purpose in this article is to show how these are the threefold ways Mathews deals with the subject of man-environment interactions. Mathews describes the various traces he left in his interactions with the environment. He also contemplates how the land imposed its mark on the Osage community. In the end, he leaves us traces on paper constituting a representation of nature, an artistic "ornamentation" which, according to him, may itself stem from "a biological urge" (3).

\section{Markings on the land}

Mathews described his environment as "undisturbed nature ever constant in subtle beauty" (1). When he went to the Blackjacks, Mathews was first confronted with the fact that his presence should not disturb nature's balance. This, however, did not mean he should not leave any markings on the land: his predicament was to find his proper place in the "balance of nature," in the "drama" of nature. In a way, he was looking for his animal place, his place as an element of nature and of his environment.

Louis Owens explored the same predicament in a short autobiographical text entitled "The Hunter's Dance." As he was fly-fishing, Owens was the witness of a "pas de deux of death" (44) between a coyote and a doe defending her newborn fawn:

Upright on precarious hind legs, the whitetail doe sparred with the coyote, jabbing spindly forelegs at his retreating face. Behind the deer, a miniscule spotted fawn lay tightly against a big log, pushing itself as far into the crease between log and earth as it could get, doing precisely what its mother had ordered. The coyote feinted and dodged and retreated as the doe advanced in her awkward, fencing stance. And then, when he had lured her sufficiently far from the fawn, he suddenly raced around her and slashed at the baby (40).

10 "I knew I should do nothing," Owens writes. However, he could not resist and, in a useless intervention into nature's drama, banged his "fly-rod case loudly against a rock" (41), thus putting an end to the dance. As he approached the fawn, abandoned by its mother, Owens realized that "already, the eyes were glazed" (41). Owens's loud banging, arising from a protective urge, had marked the land in a futile way, had created only waste. He had disturbed nature's balance because of his reluctance to accept that nature's drama is a "bloody" one (Mathews 150).

11 Another event during this trip had Owens think further about what it meant to know one's place in nature:

I'd walked maybe a quarter of a mile when I saw the first lion tracks. Nearly as large as my outstretched hand, they were superimposed over the boot tracks I'd left as I meandered upstream [...] As I tracked myself back toward camp, it became clear that the cougar had tracked me for over two miles, stepping where I'd stepped (42).

"Given the realpolitik of nature" (43), Owens writes, the logical conclusion that came to his mind was that the cougar had been contemplating the author for dinner. He then imagines the dance he had unwittingly performed, in the role of the hunted, with the cougar and concludes: "I felt strangely flattered to imagine myself thus accepted into a 
cougar's world, to be granted such a place of respect along with the deer and elk" (43). To be considered a prey by the cougar is to win one's place in the animal world. As such, the markings he left, the footprints, did not disturb nature's drama. They contributed to it. His "minuet" with the cougar, Owens calls "a brief moment of near acceptance" (44). Of course, Owens admits he would not have felt so "flattered" had he been chosen for dinner by the cougar, maybe discouraged by the "nine-foot graphite fly rod" he was carrying that might have looked like "a strange, waving antenna the cat was not predisposed to mess with" (43). Although Owens had almost won his place in the cougar's world, his graphite fly rod made him anomalous and incongruous in the eyes of the predator. Owens concludes that perhaps "[he] had been spared because unlike those other creatures I had lost my rightful place" (43).

This episode illustrates the fact that man's presence in nature is not necessarily an everlasting disturbance. Mathews's purpose was to know what his rightful place should be in the natural world. As it turns out, it takes a lot for nature's balance to be disturbed. When he came to the Blackjacks, Mathews felt that "there had been nothing from the beginning of time to upset nature's balance" (1). Yet there had been men. Travelers

must have stopped here often to rest their horses or shoot at deer, but they halted only a short time [...] Hence nature had paused and waited until the creaking and the rasping of the tires on the sandstone outcrops had died in the breezes of the prairie to the north, to resume the drama-the constant tragedy which is a part of nature's balance (2).

14 Nature is capable of adjusting to man's presence if man acts as a part of the balance and not as a controller of the balance. Man tries to control the balance when he forgets his place in nature, as when he abandons himself to economic ideologies for example, when he forgets where he comes from, quite literally in the case of the European invader whose uprootedness, according to Standing Bear, explains why "he does not understand America" nor the Indian (248). Mathews writes that the European man "has introduced insects and birds to kill economically harmful insects without considering the biological or economic result" (151). Then the European man was an "agitator of the balance" (151) and although Mathews was considered an "assimilated Indian," his text is not totally devoid of the political role of resistance typical of the writing of the colonized:

Man as an agitator of the balance in his economic business of life has also tipped the scales by introduction of species from other continents, who, in their original habitats, were kept in balance by natural enemies and limited food supply but who burst like steam from a safety valve in America, where their enemies were absent and their food supply abundant, enabling them to harass man by their numbers and overrun the habitats of indigenous species (151).

Building a house in the Blackjacks and living there, Mathews wrote, "was not disturbing a state that had been constant throughout the years, since there had been no absolute constancy to disturb" (2). Nature as a pristine space frozen in time is an illusion, a misrepresentation, "a figment of the European imagination" (Owens, "Burning the Shelter" 216), just as inaccurate and idyllic as the European invention of the noble savage leaving no markings on the land. "No two seasons and no two days had been alike through the years in the flow of earth's life toward some mysterious fulfillment, and I wanted to become a part of the flow in so far as I was able" (2). 

observed, wondered and adjusted:

the wary crows sometimes finding themselves almost immediately over the walls, before they were aware, would swerve sharply in their flight [...] and warn all crows within hearing that something strange was happening on the middle ridge; later to come back cautiously to determine just what that very interesting, extremely dangerous creature, man, was up to (11).

17 As soon as the builders left the ridge, though, the house, "with its stone colored by nature was nature's own" (17), was accepted by nature. It almost merged into its natural environment and became "a beacon" pointing south by the Canada geese for which it "looks exactly like a whimsical arrangement of sandstone" (28).

Thus, Mathews' markings on the land are puny in the context of the struggle the blackjacks have had to go through for hundreds of years in order "to survive like an animal at bay" (29), confronted with erosion, wildfire, wind and disease. The markings of an individual human being cannot vie with the eternal work of natural forces: "I, being ephemeral, cannot comprehend [the blackjacks'] struggle as a species, spread over hundreds of years, against the groping fingers of erosion, but must see them as the eternal backdrop to the drama of my ridges" (29).

For a year, he lived as part of the balance, or so he thought, not intervening in his nature's life, living noiselessly, killing or destroying nothing. "I was proud of harmony with the life about me. I became a part of it as I had wished" (59). Animals started to ignore Mathews and the puny marks he left on the land. He saw a bobcat's tracks around the house, and a skunk even came in uninvited, walked by the author reading a book in his chair, went to the kitchen, looked for food, then went out (59).

After a year, however, Mathews "broke the truce" (60) by raising animals for food. Then, he had to protect his chickens and guineas from the predators they inevitably attracted. He then realized that the balance he aspired to was reached only in violence. "With all my plans to become a part of the balance of nature on the ridges, I brought conflict" (60). This conflict, though, might make his life more natural, more fitting to the drama. Before he brought conflict by bringing his fowls, Mathews was, with his canned food, like Owens with his graphite fly rod, an anomaly: "perhaps my position was unnatural, living as I did, not from the ridge, but feeding myself artificially from cans brought from town [...] I was not a part of the economic struggle of the ridge which results in the balance, and therefore I was really an anomaly" (60). Fighting for the protection and the survival of his "charges" might have been a more natural state and in the end more satisfying than the "friends and neighbor' idea" (60). Protecting his chickens from predators, Mathews, in a way, reached by proxy the status of potential prey Owens was so flattered to have been granted by the cougar.

\section{Markings from the land}

21 As he dwelled upon the land, Mathews also came to know the markings nature left on men and on their creations, as symbolized by the "moss and lichen and ripple marks left by Carboniferous seas" on the stones he used to build his house (5). The land has as much an impact on men as men have on nature. Land and humankind interact, they rub on each other, so to speak, and this "rubbing" produces culture and history. In the 
words of environmental historian William Cronon, "all history is a long-standing dialogue between human beings and the earth" (25).

Mathews was one-eighth Osage, the descendant of a white missionary and mountain man, and an Osage woman. Although he was raised in Pawhuska, Osage Country, Oklahoma, Mathews grew up as an observer of Osage culture rather than a participant. Ruoff writes that because his Osage lineage was matrilineal in a patrilineal society, he was not allowed to partake in ceremonies. According to Wilson, Mathews's family being mixed-blood was the reason for their being set apart, although not completely socially ostracized. Both John Joseph and his father, who owned a store in Pawhuska, spoke at least some Osage, and "the ethos of traditional Osage culture permeated the life" of the family: "The entire family found itself in close juxtaposition to the tribespeople who came to trade at the store, but the Mathews family, father and children, were of mixedblood and thus apart" (Wilson 266-267). Yet Mathews was very interested in and fascinated by Osage culture, as manifested by his writings and other achievements ${ }^{1}$. In the introduction to his history of the Osages, Mathews wrote that he was a small boy in Pawhuska "when the seed which was to disturb me all of my life was planted" (The Osages $\mathrm{x}$ ). Alone in his room, at night, he would hear "a long, drawn-out chant broken by weeping" (xi). This sound, he would hear "many times later as I grew up and up until the time I entered high school, and I have never been able to describe it to myself; it was indescribable, and there is nothing with which to compare it. It filled my little boy's soul with fear and bittersweetness, and exotic yearning, and when it had ended and I lay there in my exultant fear-trance, I hoped fervently that there would be more of it, and yet was afraid that there might be" (xi). In 1932 he would return to the Osages to live and work with them, notably as an elected member of the tribal council where he served two terms (Ruoff 7).

Talking to the Moon is the literary result of his endeavors to understand Osage culture by understanding their connections to the land. At the same time, it is the result of his search for his own place within Osage culture and land. Ruoff writes that contrary to previous Native American autobiographies, "Talking to the Moon is not an exploration of Mathews's ethnicity but rather a chronicle of his attempts to find himself at a crucial time in his life through rediscovering the land, animals, and people of his native Oklahoma" (5). Another way to see it is as a rediscovery of his ethnicity by way of observing the land of his people.

More than a mere reflection on the environment of its author, Talking to the Moon is an assessment of the culture of the Osage, and an attempt at understanding how this culture was determined by the land that the Osage occupied. Mathews writes of the "indigenous development" of a culture and indigenous needs to be taken quite literally to mean engendered by the land. He writes that "indigenous development of the nervous system into thought-processes reached its heights in articulate speech, thoughtinfluenced social and economic organization, artifacts, and the religion of Wah-KonTah" (222), the name the Osages give to the divine, the Mysterious Power (La Flesche 48). On a more personal note, he considered his own thoughts and philosophical considerations indigenous. They came to him, as "seeds" of thoughts, when he was out in nature, hunting or riding-he calls them his "saddle-dreams" (207): "they are like desert seeds springing up when the conditions are right, perhaps even to bloom, when I occasionally sit all night by the fire. But they come from the ridges and the blackjacks" (207). When these seeds bloom into fully-fledged thoughts, but thoughts that do not 
lead him into any animal action toward survival or reproduction, they are then "ornamental. They have nothing to do with earth-law of survival" nor are they "under the influence of the other earth-law, reproduction" (215).

Survival and reproduction, according to Mathews, are the two "primal laws" by which animal actions, including men's actions, are determined. These actions are relatively easy to observe and explain. However, Mathews observes a third type of action not always as easy to assess that he calls "ornamental." The coyote howling for no apparent reason, or "talking to the moon," is the most fascinating example of such "ornamental expressions" around him. But such apparently useless animal actions are fairly abundant. He notices that the crows, because they are "unable to sing or dance," are collecting and hiding bright objects to enjoy them later in solitude. The song of some birds, out of mating season, Mathews sees as "the expression of mating emotion that has spilled over" (206). These "ornamental expressions" cannot be explained by the two primal earth-laws (207). Their function has nothing to do with either survival or reproduction. Yet, he wrote, "every thing and every action on my ridges and among my blackjacks have meaning, and the better I understand the raison d'être of these things and these actions, the more intense my pleasure, even if I can satisfy myself with plausible guessing in many cases" (207). These considerations and the time and energy Mathews dedicated to understanding these natural manifestations might gainsay paleoanthropologist Pascal Picq, who wrote that "it is so self-evident to Homo Sapiens that the other species are moved only by their instincts that one never really wondered whether poetry could have its place in nature" (24; my translation). Mathews did wonder about that, but he might have thought that this poetry was an instinct.

One purpose of Mathews in coming back to the Blackjacks was to

find some connection between man's artificial ornamentation and the useless ornamentation among the creatures of my little corner of the earth. I realized that man's artistic creations and his dreams, often resulting in beauty, as well as his fumbling toward God, must be primal, possibly the results of the biological urge which inspires the wood thrush to sing and the coyote to talk to the moon (3).

His observations and reflections led him to argue that these seemingly "useless" expressions are manifestations of a "third urge" which is as natural as the first two. These urges stem from what he calls "the Force," or "the biological impulse." Human ornamental expressions are of the same order as the coyote's talking to the moon, in themselves not more or less significant. They were simply "made important with the development of man's ability to reason" (216). In a sense, it is because men had to reason out an explanation for their own talking to the moon, their "fumbling toward God" (16), that they called it religion.

When Mathews thinks about the Osage-the "Homo Sapiens who was a part of the balance of my blackjacks" (221) - he understands that his culture is as much a product of his natural environment as the talk of the coyote or the song of the mockingbird: "he was almost as much under the influence of his natural environment in his man-world of thought as he was in his animal-world of struggle and reproduction" (221). Even the Osage's "concept of God [...] was certainly colored by his natural environment and fear of the elements and his enemies" (221). Because the Osage man sensed a duality between "two natures" (221), "he divided himself and his universe into two parts, man and animal, spiritual and material, sky and earth" (221) which he called Chesho and Hunkah. ${ }^{2}$ Chesho, the elevation of men to ornamental expressions; Hunkah, the primal earth-law actions. Wah-Kon-Tah, then, did not create men; but men, under the 
influence of their environment, invented the religion of Wah-Kon-Tah, as well as other cultural practices:

When the Force urged him to expression, he turned his eyes to Grandfather the Sun; the colors he saw under his closed eyelids he put into beadwork, quillwork, and painting, as inspirations from one of the greatest manifestations of the Great Mysteries, the sun, father of Father Sky, impregnator of Mother Earth (221).

In The Way to Rainy Mountain (1969), Momaday also tells of the invention of the Kiowa culture by virtue of the dialogue between man and nature. During the migration that took them from the confined forests of Yellowstone to the southern Plains, the Kiowas became what they were. Getting out of the forests, they saw the earth unfold and the limit of the land recede (The Way to Rainy Mountain 7). "Clusters of trees, and animals grazing far in the distance, cause the vision to reach away and wonder to build upon the mind" (7). This wonder would lead the Kiowas to "fumble toward God," in the words of Mathews. There in the plains, the sun takes another dimension: "The sun is at home on the plains. Precisely there does it have the certain character of a god" (7). At the end of their trip, the Kiowas had developed the Sun Dance religion.

\section{Markings about the land}

When his fireside thoughts did not lead to resolve or action, they might lead to "ornamentation in word symbols" (215), as Mathews referred to writing, likened to what the Force does when it makes the coyote talk to the moon.

The urge to produce these "word symbols" is both frustrating and necessary. Frustrating because inadequate to express the glory of nature, simply a pale representation of the real thing. Necessary because these ornamentations are the markings which will preserve the memory of threatened cultures.

When hunting, that is when he is an animal surrounded by nature, "small and overpowered by the primitive forces" (177) as Owens aspired to be when tracked by the mountain lion, Mathews experienced "the only true freedom that man can feel; the serenity that comes with the absence of emotion and the complete absence of man's pitiful urge to express himself" (177). This freedom from expression is "the only complete contentment" (177). Thoughts are sufficient then, thoughts impregnated in man by nature, passing by like a breeze, without stopping long enough to grow into resolve. "How satisfying it is to be free from slavery, free from sad little attempts to express the mystery of disturbing life, and to escape the pain that such questing brings" (177). The only way to fully express oneself in one's relationship to the land is by physical action: "physical action and living to the very brim each day in harmony with the life about me were exhausting and therefore completely satisfactory" (16). Markings about the land, then, expressions of what comes from the land can be painful because they take one away from the flow of nature, even by the narrowest margin. True contentment comes from abandoning oneself to the flow of nature, without stopping to explain nature.

This contentment and this glory are impossible to express in "word symbols" (183). "Why should I spend the golden hours attempting to express my thoughts and emotions in word symbols when I can't do so adequately" (183). One can feel the glory of nature by experiencing it directly but one cannot give it to someone else to feel by 
proxy. Representations of nature are never good enough to account for the glory of nature. Attempts at representing nature can only be puny markings.

Yet these markings are also necessary and as irrepressible as the wrens' frantic nestbuilding. Having to destroy a nest the wrens had built in the pocket of a jacket he had hung on the fence, he consoles himself with the thought that "inasmuch as they are incessant nest-builders anyway, this nest in my pocket was only an overflow expression and had nothing to do with the harsh business of life; an ornamental expression very much like the manuscript which lay neglected on my desk" (49). When they reach elaborate stages, these ornamental expressions become culture and they can "create beauty" (16). Man's religion and man's art, all "ornamentations," are all at the same time markings of the land on the community and, as interpretations of the land, the community's markings about the land. These interpretations-all together forming culture-are what enable men to come to terms with their environment. Consequently if a foreign culture-that is a culture that the land has not shaped-is imposed on a land, not only does it create confusion and disruption, it is also ugly because uprooted and out of place. In Sundown, a novel Mathews wrote while he was living in the Blackjacks, Chal, the mixed-blood Osage protagonist, looks at the landscape on his train-ride to the university and tries to understand the reason for such ugliness:

Chal did not know the reason for this ugliness; this ugliness which white men seemed to produce. He did not know that these buildings were expressions of a race still influenced by an environment thousands of miles across the ocean, and that these foreign expressions were due to the fact that the race was not yet in adjustment with the new environment. He felt simply that these things were not beautiful (90).

The Osage religion and ceremonies had enabled the Osage men to know their land and to live as part of its balance, but Christianity and mechanization has not only destroyed social structures shaped by a given environment but also wiped out all images of the land that made sense to its human inhabitants. In Mathews' days, the old men of the tribe were going through a difficult period: they saw "the end of their race, the end of their god, the complete assimilation of their children, and the end of their immortality" (86). A culture foreign to their land had come as "the sheet-water of oblivion that washes their moccasin prints from the ridges" (86). The third urge makes them desperate now to leave their "moccasin print" in the "thoughts or consciousness of [their] descendants" (86).

The "moccasin print" is not only the story of an individual, not only how an individual marked the land. It is also about how the land marked the individual, and markings about all this become necessary for preservation of memory, history and identity. Thus an elder chief of the Osage, Eagle-That-Gets-What-He-Wants, and his wife visited the author to ask him to accomplish this task: "'He says he wants to talk to you. He said when he is gone young people might forget things. He wants you to write these things down. [...] Seems like now these things will not be remembered by the people who will follow, if you do not write them down in book'" (86). A moccasin print is what is left behind after an individual has had a dialogue with the land; the sum of moccasin prints is history. It is important for future generations to be conscious of what Indians left behind, of their history, of the fact that they did leave markings on the land, instead of passing on it without impacting it in any way. The old chief knows he "cannot depend upon the father-to-son method of history impressed on the minds of the succeeding generations by constant repetition" (89) and he does not want to "be cheated of that 
very precious immortality which is the tribal memory" (89). The word symbols will ensure that his moccasin print remains. The preservation of this and other elders of the Osages is a task that Mathews undertook for many years of research and of listening to oral stories, all of which would result in The Osages: Children of the Middle Waters, a history of the Osage published in 1961, which is still a reference today. In a way, Talking to the Moon is Mathews's own moccasin print. He writes an autobiographical work, yet one does not learn much about Mathews's rich career and achievements, usually the objects of an autobiography. One does not learn much about his social interactions and accomplishments either. One learns, however, a lot about his interactions with his environment, one reads the dialogue he had with the land and what this dialogue produced. The book is an amateur naturalist's account of his observations of "nature's drama," a representation of nature and more specifically of the environment of which he was a part and which he marked as such, and an autobiographical account of the markings he left in the world. In previous studies of Momaday's autobiographical work, I used the term auto-topo-graphy for this kind of work. Mathews and Momaday actually describe the life of a landscape, and the traces they left on that landscape, in order to write about themselves. Borrowing from Michel Serres's concept of Biogée, I think that the term auto-biogeo-graphy might be more adequate, at least to define Mathews's work. Biogée is how Serres calls "the Earth and all the living species" (33; my translation) taken together, as one living, even cognitive, interlocutor of man. Taking up Aldo Leopold's project of thinking like a mountain, Serres urges men to try and think like Biogée. To do that, one must first consider Biogée like a fellow being-not an object-on an equal footing with man, and love it as such. One must stop waging war against Biogée (31). Serres argues that once one understands Biogée, then it becomes the matrix of a new knowledge beyond the traditional Western separation of nature and culture. "Human: 100\% nature, 100\% culture. Biogée covers all" (58). Learning to think like Biogée seems to be Mathews' undertaking. He talks to the land, and the land talks back and tells him its story, a natural story and a cultural one at the same time, the story of a human culture stemming from nature. Talking to the Moon is an account of this conversation.

\section{Conclusion}

The romantic image of the Indian as leaving no markings on the land is as dehumanizing a definition as the image of the Indian as a bloodthirsty cannibal and a wild beast. As William Cronon points out, "the myth of the wilderness as 'virgin,' uninhabited land had always been especially cruel when seen from the perspective of the Indians who had once called that land home" (15). One might add that from the Osage perspective, the land was no virgin to rape, but a mother that had been impregnated by Father Sky, giving birth to the people.

Mathews was a twentie th century one-eighth Osage Indian. However "assimilated" he might have been, his book offers a very perceptive philosophical reflection on the interactions that the Indians, the Osages in particular, as all men, have had with their environment. He forcefully and convincingly reasserts that yes, the Indians "have made a footprint" on the land.

The title of this article comes from an Osage song that Mathews wrote down in his book after hearing it from an elderly woman of the tribe: "I have made a footprint, a sacred 
one / I have made a footprint, through it the blades push upward, etc" (48). This song is a ceremonial song that women sang as they were planting corn, making small mounds, making holes in the top of the mounds with a pole, putting corn in the holes and then tamping down the dirt with their feet: "We stand on them little hills and make drum against the earth with them poles and sing purty song," Mathews' informant, Ee-NahApee, explains (48). The line I used as a title can symbolize the relationship man is supposed to have with nature, as illustrated by the whole book: man does mark the land, but nature overcomes this mark, pushes through it to give something back to man. Far from being destructive, this footprint is productive.

This is where Mathews's work probably differs fundamentally from Thoreau's. Thoreau's experiment remains primarily a personal one. Mathews ponders over how his people's culture is produced by a specific place, making this culture indigenous, literally, that is engendered by the place man interacts with. By definition, Thoreau cannot understand his people by observing nature in Concord since that place did not produce his people's culture. The nature of the footprint might be a characterisitic difference between the work of Thoreau and that of Mathews. Both men came from two opposite worldviews which made them look differently at the footprint they left on the ground. While Thoreau, coming from a people who had tried to conquer and master nature, was careful to leave the smallest footprint possible, Mathews, coming from a people who had been dehumanized as being part of the wilderness, is endeavouring to assess and emphasize the footprint his people left. While Thoreau went to the woods to escape society, Mathews "wasn't attempting to escape anything when [he] came to the blackjacks" (16). In fact, he went there to actually understand the world, the Osage world and culture and worldview.

\section{BIBLIOGRAPHY}

Cronon, William, and Richard White. "Indians in the Land." American Heritage 37.5 (AugustSeptember 1986): 19-25.

Cronon, William. "The Trouble with Wilderness: or, Getting Back to the Wrong Nature." Environmental History 1.1 (January 1996), 7-28.

Krech, Shepard III. The Ecological Indian: Myth and History. New York: W. W. Norton, 1999.

La Flesche, Francis. The Osage Tribe. Rite of the Chiefs; Sayings of the Ancient Men. Thirty-Sixth Annual Report of the Bureau of American Ethnology to the Secretary of the Smithsonian Instituion 1914-1915. Washington: Government Printing Office, 1921. 37-599. http://ia700201.us.archive.org/2/items/ osagetriberite00laflrich/osagetriberite00laflrich.pdf

Larré, Lionel. “N. Scott Momaday's West.” Exploring the American Literary West: International Perspectives. Eds. David Rio, et al. Bilbao : Universidad del Pais Vasco, 2006. 141-149.

Larré, Lionel. Autobiographie amérindienne. Pouvoir et résistance de l'écriture de soi. Pessac: Presses universitaires de Bordeaux, 2009. 
Mathews, Elizabeth. "Foreword." Talking to the Moon. Norman: University of Oklahoma Press, 1981. ix-xi.

Mathews, John Joseph. Talking to the Moon. 1945. Norman: University of Oklahoma Press, 1981.

Mathews, John Joseph. The Osages: Children of the Middle Waters. Norman: University of Oklahoma Press, 1961.

Momaday, N. Scott. The Way to Rainy Mountain. Albuquerque: University of New Mexico Press, 1969.

---. “An American Land Ethic.” The Man Made of Words: Essays, Stories, Passages. New York: St Martin's Griffin, 1997. 42-49.

Owens, Louis. "Burning the Shelter." Mixedblood Messages. Literature, Film, Family, Place. Norman: University of Oklahoma Press, 1998.

---. “The Hunter's Dance.” I Hear the Train. Reflections, Inventions, Refractions. Norman: University of Oklahoma Press, 2001.

Picq, Pascal, Jean-Louis Dessalles et Bernard Victorri. Les origines du langage. Paris : Le Pommier, 2006.

Pughe, Tom and Michel Granger. "Introduction." Ecrire la nature. RFEA n 106 (décembre 2005) : 3-7.

Rigal-Cellard, Bernadette. Le Mythe et la plume : la littérature indienne contemporaine en Amérique du Nord. Paris: Editions du Rocher, 2004.

Ruoff, A. LaVonne Brown. “John Joseph Mathews's Talking to the Moon: Literary and Osage Contexts. Multicultural Autobiography: American Lives. Ed. James Robert Payne. Knoxville: University of Tennessee Press, 1992. 1-31.

Serres, Michel. Biogée. Paris: Le Pommier, 2011.

Standing Bear, Luther. Land of the Spotted Eagle. 1933. Lincoln: University of Nebraska Press, 1978. Thoreau, Henry David. Walden, or Life in the Woods. 1854. Edition used for this article: New York: Signet Classics, 1999.

White, Eugene Edmond. Experiences of a Special Indian Agent. Norman: University of Oklahoma Press, 1965.

Wilson, Terry P. "Osage Oxonian: The Heritage of John Joseph Mathews. Chronicles of Oklahoma 59.3 (Fall 1981): 264-293.

\section{NOTES}

1. Four of the five books Mathews published are about the Osages. In 1932, he published his first novel, Wah'Kon-Tah: The Osage and the White Man's Road (Norman: University of Oklahoma Press). In 1934, he published Sundown (Longmans, Green and Co.), telling the story of Chal Windzer, a mixed-blood Osage who attends college after growing up on the reservation and tries to come to terms with his mixed ancestry. His last production after Talking to the Moon is entitled The Osages: Children of the Middle Waters (University of Oklahoma Press, 1961). It is a history of the Osages, which Mathews accomplished after years of research and interviews with Osage elders. Mathews also manifested his interest in the Osages by serving in the national council for several years and by being instrumental in establishing the Osage Tribal Museum, in Pawhuska. 
2. Ethnologist of the Osage Francis LaFlesche tells us that the ancient "who formulated the organization of the people made it religious in character and based it upon the duality they observed throughout nature. These thoughtful seers had arrived at the conception that all life issues which take on manifold form result from the combined influence of two great physical forces-namely, the Sky, including the heavenly bodies, and the Earth, including the waters distributed over it. This duality they represented in the tribal organization, the Tsi'-zhu great division representing the Sky, the $\mathrm{Ho}^{\mathrm{n}}$ '-ga great division the Earth" (LaFlesche 59).

\section{ABSTRACTS}

The purpose of this article is to analyse the representation of nature that John Joseph Mathews published in 1945, in Talking to the Moon, a book commonly referred to as a Native American Walden. In the 1930s and 1940s, Mathews (1895-1979), a member of the Osage tribe, spent ten years in the Blackjacks, an isolated spot a dozen miles away from Pawhuska, Osage County, Oklahoma, named after the oak trees that cover the hills. In Talking to the Moon, Mathews observes his environment, writes down his reflections on the human impact on nature, but also the impact nature has on men, and on the Osages in particular.

L'objectif de cet article est d'analyser la représentation de la nature de John Joseph Mathews, qui publia en 1945 ce qu'il est convenu d'appeler un Walden amérindien. Dans les années 1930 et 1940, Mathews (1895-1979), membre de la tribu des Osages, a passé dix années dans un coin reculé de ses terres familiales qu'il appelle les Blackjacks, d'après le petit chêne qui en couvre les collines, dans le conté Osage au nord-est de l'Oklahoma. Dans Talking to the Moon, un texte entre autobiographie et écrit naturaliste, Mathews livre ses observations de son environnement, ses réflexions sur l'impact que l'homme-lui-même en particulier-laisse sur la nature, mais également sur celui que la nature laisse sur l'homme.

\section{INDEX}

Keywords: Native American literature, environment, representation of nature, autobiography Mots-clés: littérature amérindienne, environnement, représentation de la nature, autobiographie

\section{AUTHORS}

\section{LIONEL LARRE}

Maître de conférences

Université Michel de Montaigne, Bordeaux 3

Lionel.Larre@u-bordeaux3.fr 